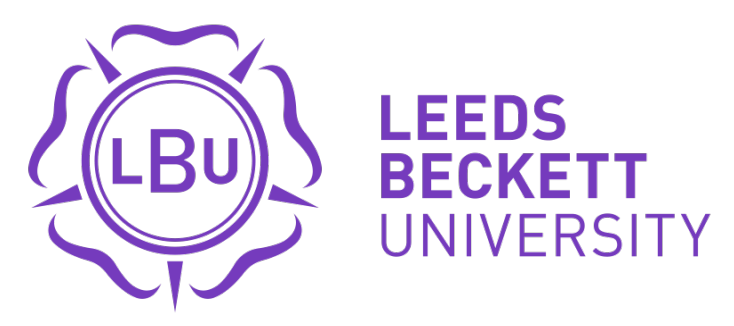

Citation:

Peeroo, S and Samy, M and Jones, BT (2017) Facebook: a blessing or a curse for grocery stores? International Journal of Retail and Distribution Management, 45 (12). ISSN 0959-0552 DOI: https://doi.org/10.1108/IJRDM-12-2016-0234

Link to Leeds Beckett Repository record:

https://eprints.leedsbeckett.ac.uk/id/eprint/4020/

Document Version:

Article (Accepted Version)

The aim of the Leeds Beckett Repository is to provide open access to our research, as required by funder policies and permitted by publishers and copyright law.

The Leeds Beckett repository holds a wide range of publications, each of which has been checked for copyright and the relevant embargo period has been applied by the Research Services team.

We operate on a standard take-down policy. If you are the author or publisher of an output and you would like it removed from the repository, please contact us and we will investigate on a case-by-case basis.

Each thesis in the repository has been cleared where necessary by the author for third party copyright. If you would like a thesis to be removed from the repository or believe there is an issue with copyright, please contact us on openaccess@leedsbeckett.ac.uk and we will investigate on a case-by-case basis. 
2 emerald International Journal of Retail \& Distribution Management

Facebook: a blessing or a curse for grocery stores?

\begin{tabular}{|r|l|}
\hline Journal: & International Journal of Retail \& Distribution Management \\
\hline Manuscript ID & IJRDM-12-2016-0234.R2 \\
\hline Manuscript Type: & Research Paper \\
\hline Keywords: & $\begin{array}{l}\text { Social media, Customer engagement, Relationship marketing, Customer } \\
\text { Empowerment, Retail sector }\end{array}$ \\
\hline \multicolumn{2}{|l}{} \\
\hline
\end{tabular}

SCHOLARONE

Manuscripts 


\begin{abstract}
Purpose - Increasingly businesses are using Facebook to communicate and engage their customers. However, there is a dearth of research as to why and how customers interact with businesses on social media in the grocery sector. Therefore, this paper aims to explore the roles played by online brand communities (OBCs) and social customers in the creation as well as the destruction of value.
\end{abstract}

Design/methodology/approach - Netnography was adopted as an approach to gain insight into the various ways customers engage with grocery stores on their official Facebook pages. Messages posted on Tesco's and Wal-Mart's Facebook pages are thematically analysed and critical discussion is linked back to the extant contemporary debate on social media.

Findings - This study shows that customers respond to company posts for the following reasons: to communicate with the stores, to converse with other customers, to express their emotions, to share their experiences as employees of the stores with customers, and to share their positive or negative actions with members of the online communities. The study further highlights the role of social media in the co-creation and co-destruction of customer, consumer and supermarket value and builds contemporary theory and informs practice.

Practical implications - Retailers should use social media to enrich the customer experience by encouraging customer engagement, co-creation of value and responding efficiently to customer needs in real time.

Originality/value - This paper contributes to knowledge by uncovering the various ways customers react with the business. The social customer is both a curse and a blessing to Tesco and Walmart as they can create or destroy value for the business.

Keywords — social media; customer engagement; relationship marketing; customer empowerment; retail sector 


\section{Facebook: a blessing or a curse for grocery stores?}

\section{Introduction}

The web has created numerous channels where customers share opinions on products, services and brands (Tiruwa et al., 2016). Vast arrays of social networks are now the platforms where brand related conversations occur between a company and its customers and among customers (Hennig-Thurau et al., 2013, Yadav, 2015). Currently, businesses of all sizes are experimenting with social media marketing, dealing with the question of how to get in on what appears to be an especially viral way to get their message and their products promoted (Labrecque, 2014).

With the advent of Internet technology, communities of consumers shifted online and more than 50 percent of the top 100 global brands have an online brand community (OBC) (Manchanda et al., 2012). Businesses within most sectors are drawn by the potential benefits of adopting social media platforms (Ureña et al., 2015). Research shows that managers have joined the social media world fearing to lose the social media battle, which highlights the importance of relationship marketing in the technology era. (Harvard Business School, 2010, cited in Schultz and Peltier, 2013). Yet, many managers are still unsure of the opportunities and threats pertaining to social networks. However, in practice companies seem to be exploiting social media just as any other conventional communication medium and they are not directly interacting and are not actively seeking to obtain highly engaged customers through social media. Companies fail to make digital platforms engaging and valuable to customers (Schultz and Peltier, 2013). It is therefore crucial for businesses to understand why and how customers engage with corporate social media platforms.

Retailers need to understand how during a single visit on an online platform, they might grasp customers' attention, build a relationship with them and convince them to commit themselves within an increasingly fragmented, interactive and complex retail environment (Demangeot and Broderick, 2016). Tsimonis and Dimitriadis (2014) suggest that further research be carried out to understand the expectations and motivations of customers who are interacting with businesses on social media. Anderson et al. (2014) studied the motivations of customers for engaging and interacting with apparel retailers on social media and recommended further research in different retail sectors. Responding to these calls for research, this paper focuses on the grocery sector to provide knowledge as to why customers engage and interact with such businesses on their Facebook pages. Unlike the apparel sector where customers are highly involved in the purchase decision, the grocery 
sector offers products such as food where customers display a lower level of involvement. So, the main purpose of this research is to analyse how customers react to corporate messages on the official Facebook page of grocery stores to gain an understanding as to what motivates customers to interact with such businesses via social media. The aim of this paper is to explore the roles played by OBCs and social customers in the creation as well as the destruction of value.

The paper is organised as follows. It begins with a literature review, which examines the main concepts of social media, customer empowerment and customer engagement. The netnography method is then outlined and is followed by an analysis and discussion of the findings. Finally, the conclusion, limitations, and suggestions for future research directions are then presented.

\section{Literature review}

Social media have gained wide acceptance and are heralded as a social media revolution (Arnaboldi and Goget, 2016; Jurgens et al., 2016). Social media platforms bring together people having a commonality of thought, interest and involvement in products, services, issues or lifestyles (Kozinets, 2002). Corporations have been engulfed in the new wave of technology, which allows for instantaneous communications with their customers, which is vital for reputation management and business sustainability.

\subsection{Social media within a business context}

With the advent of social media, OBCs can be created at a low cost, hence providing opportunities to businesses to add value to existing brands and to build stronger and more meaningful relationships with their customers (Gonzalez-Lafaysse and Madrid, 2016, Wirtz et al., 2013). Additionally, OBCs being interactive provide mutual benefits as businesses learn about customers' perceptions of their brands and products. As such customers are exposed to a plethora of information from the company and from the user generated content (UGC) created by the OBC members (Wirtz et al., 2013).

The growing popularity of Web 2.0 and social media has fundamentally modified how customers interact with companies and brands online. They adopt a social approach while using online platforms (Malthouse and Hofacker, 2010; Yadav and Pavlou, 2014). Greenberg (2010) describes the social customer as someone who is connected to peers through the web or mobile devices, who expects to get information as and when needed and who is willing to share this information to other customers on social media platforms. Web 2.0 applications 
made it easy for individuals to generate information and to give easy access to information to others (Constantinides et al., 2008; Shao, 2009).

\subsection{User Generated Content and customer empowerment}

Social media offer a platform to customers to create and share UGC on OBCs, thus adding value to the brand (Tiruwa et al., 2016). Muntinga et al. (2011) refer to all UGC related to brands as COBRA i.e. Consumers' Online Brand Related Activities. They identified three distinct levels of involvement with UGC, namely: consuming, contributing and creating. The consuming COBRA type represents the lowest level of involvement and indicates participating without actively contributing to or creating content. The contributing COBRA type is the intermediate level of online brand-related activeness. Customers who contribute to brand-related content join and participate in a conversation on a brand's fan page on a social networking site, contribute to brand forums, and post comments on blogs, videos, pictures, and any other brand-related content generated by others. Finally, the creating COBRA type is the utmost level of online brand related activeness. Those customers actively produce and publish brand-related content that others consume and contribute to. Web 2.0 has empowered customers by giving them a voice through their UGC (Constaninides et al., 2008).

Kimmel (2010) argues that customers are no longer content to select goods produced, distributed and promoted by companies, which determines what customers want and need. In consumer-to-consumer (C2C) marketing, consumers are increasingly taking control of the marketplace and they take a more active role in marketing functions such as the creation or modification of products (Kimmel, 2010). In addition, Blasco-Arcas et al. (2016) argue that $\mathrm{OBCs}$ enable both customer-customer and customer-firm interactions and that these interactions make customers feel empowered. When customers perceive that they have been empowered, they engage with, trust and feel passion and pride for the brand (Hollebeek, 2011). Therefore businesses need to respond to the social media consumer if companies do not want to experience the negative consequences of consumer backlash on a public platform (O'Brien, 2011). Businesses that embrace social media as a strategy must acknowledge that they are losing an element of control to the consumer (O'Brien, 2011; Horn et al., 2015). Among the various social media platforms, Facebook is the platform that has been widely adopted by brands and companies (Ho, 2014). 


\subsection{Facebook, a corporate marketing tool}

Facebook is the most popular social media platform worldwide (Pereira et al., 2014) boasting 1.23 billion active monthly users (Facebook, 2014, cited in Ballings, and Van den Poel, 2015). As of June 2016, it stands at 1.67 billion users and the growth rate is phenomenal (http://www.internetworldstats.com/facebook.htm). Unlike other social media platforms, Facebook actively seeks to attract businesses to use their medium as a marketing tool by enabling users to access the network through applications and also gaining access to corporate websites via social plug-ins (Pereira et al., 2014). In a recent worldwide study by Reuters, it was revealed that more than $50 \%$ of the respondents read their news through social media and Facebook is their main source (Newman et al., 2016). Business understands the market share of Facebook in reaching to audiences through a unique progressive design that connects people worldwide.

Typically businesses set up a single Facebook account or several Facebook accounts to connect and interact with their customers via wall posts (Jansen et al., 2009). When a fan 'likes' a post and engages with the post, the message may appear in the news feeds of his/her friends on Facebook. Therefore, Swani et al. (2013) contend that 'liking' is comparable to word of mouth (WOM) since individuals share the messages they like with each other. De Vries et al. (2014) argue that the number of 'likes' indicates the popularity of the post and encourages customer engagement (CE). Additionally, corporate Facebook pages are OBCs as the fans who have 'liked' the page share a common interest (Pöyry et al., 2013). Kietzmann et al. (2011) and Fournier and Avery (2011) caution businesses of the dangers in starting or manipulating conversations on social media. Customers tend to resent marketing messages on social media platforms, which they mainly use to connect with family, friends and colleagues. As this new marketing paradigm evolves, there is genuine excitement about the potential of social media to add value for businesses, but also apprehension about the difficulty of seizing the full promise of this new medium (Lipsman et al., 2012, Newman et al., 2016).

\subsection{Social media: Benefits and opportunities}

In this social media age, businesses have the opportunity to reach out and communicate to customers anywhere in the world and at any time, they can even interact with customers and join their conversations (Kietzmann et al., 2011; Rao, 2012). The ease and speed with which information can be retrieved and shared, the ability to engage with stakeholders, the richer experiences for users, and enhanced web metrics are just a few of the positive impacts that have encouraged many organisations to use social media communication (Postman, 2009, 
cited in Lovejoy et al., 2012). Lipsman et al. (2012) and Wirtz et al. (2013) contend social media can help companies engage and build long-term loyalty with existing customers, connect with new customers, and grow their business.

Park and Kim (2014) identified four benefits that customers gain from using social networks: social benefits by interacting with other members of the community, informational benefits by accessing information about the products and services of the company, hedonic benefits, by enjoying and having fun on the social network for e.g. games, and finally economic benefits by obtaining promotional deals. These benefits encourage community members to continue visiting and being active on social networking sites, therefore offering opportunities to firms to strengthen relationships with their customers.

Additionally, tools of Web 2.0 seem to ease co-creation of value by the company and the customer (Harrisson and Barthel, 2009; Thackeray et al. 2008). Co-creation "involves [customer] participation in the creation of the core offering itself $[\ldots]$ through shared inventiveness, co-design or shared production of related goods" (Lusch and Vargo, 2006, p. 284). It is argued that Web 2.0 is the paradigmatic domain of the 'prosumer' (consumer and producer), where consumer-produced content, especially reviews of products and services posted on social media, influence both customer and company behaviour (Ritzer and Jurgenson, 2010). Consumers are encouraged to actively participate in the creation of new products by suggesting and evaluating new product ideas; developing, assessing and challenging product concepts; discussing and improving prototypes; testing and experiencing the new product features by running simulations; and requesting information about or just consuming the new product (Füller et al., 2009). Co $\square$ creation activities on the Internet contribute to perceived consumer empowerment (Füller et al., 2009). According to O'Brien (2011), the highest level of value a social media empowered consumer can provide to a business is to co-create products and services. Vargo and Lusch (2010) define CE as customer experience co-created with a company. CE refers to the customer's physical, cognitive and emotional connection with the business (Patterson et al. 2006).

CE is defined as "a customer's behavioural manifestations that have a brand or firm focus, beyond purchase, resulting from motivational drivers" (van Doorn et al., 2010, p. 254). This definition highlights that behavioural manifestations do not only mean purchases, but also include other activities of the customer such as WOM, customer co-creation and complaining behaviour (Bijmolt et al., 2010), recommendations, helping other 
customers, blogging, writing reviews and even engaging in legal actions (van Doorn et al., 2010). The consequences of this consumer engagement process are consumer satisfaction and loyalty, consumer empowerment, connection and emotional bonding, trust and commitment (Brodie et al., 2011b). Gummerus et al. (2012) found that CE activities in OBCs result in perceived economic, social and entertainments benefits, while Pongpaew et al. (2014) report that customers seek informational, entertainment, economic and selfportrayal benefits when engaging with brands on Facebook. Moreover, Abdul-Ghani et al. (2011) show that customers engage with firms to obtain hedonic, utilitarian, reputation and enhanced knowledge benefits.

\subsection{Social media: challenges and threats}

The advent of social media brings along numerous threats to businesses (Horn et al., 2015). There are three major sources of threats to organisations: (1) empowered customers who can spread rumours and complaints in a very short time span, (2) employees who can either deliberately voice their discontent as private social media users and/or they can involuntarily harm the reputation of the company while being responsible for managing the social media accounts of the organisation, (3) the corporation itself which may not use a social media platform or may not have a web care team, therefore preventing the business from detecting and reacting to online discussions and comments about the company and its products and services (Horn et al., 2015).

Complaints are rife on social media platforms and are a specific form of negative WOM (Einwiller and Steilen, 2015). The voice of the consumer may turn into a potentially serious threat when it carries negative content (Lee et al. 2014). Co-destruction of value may occur where value is destroyed either for all parties or for one party only (Plé and Chumpitaz Cáceres, 2010). Co-destruction denotes the joint destruction, or impoverishment of value by businesses and customers (Echeverri and Skålén, 2011). Additionally, Smith (2013) found that codestruction of value occurs whenever dissatisfied customers seek revenge from the company for e.g. by engaging in negative WOM with the intent to cause corporate reputational damage.

Leeflang et al. (2014) argue that when organisations fail to engage customers they have to face the potential threat of customer enragement, a situation where customers can easily become value destroyers instead of value creators for companies (Verhoef et al., 2013; Verhoef et al., 2010). Businesses are then compelled to be reactive, or even pro-active, to avoid negative brand image consequences which in turn may lead to increased value co-destruction. 
Consequently Jin (2012) refers to social media as Pandora's box because they can perform as a virtual brand community as well as a virtual anti brand community. Anti brand communities are groups of users who organise group actions against a brand and become a forum where customers express their discontent; where anti brand information is exchanged and lawsuits and boycotts are encouraged (Krishnamurthy and Kucuk, 2009).

Similarly, Champoux et al. (2012) contend that the open-comment platform of Facebook and the anonymity offered by the Internet produce the ideal conditions for public outrage to be vented on corporate walls. Furthermore, Horn et al. (2015) argue that social media have empowered customers and the public by giving them a voice and weakened the position of companies by rendering them vulnerable to customer attacks, negative publicity and corporate reputation damage. Additionally, Pfeffer et al. (2014, p. 118) found that social media users can generate an online firestorm, which they define "as the sudden discharge of large quantities of messages containing negative WOM and complaint behaviour against a person, company, or group in social media networks". Similarly Horn et al. (2015) refer to repetitive and systematic customer attacks as 'shitstorm'. A shitstorm denotes emotional and often irrational criticisms carried out by many consumers. Rational negative opinions usually form the basis for shitstorms, which eventually grow through irrational and assertive content added by other dissatisfied users.' (Horn et al., 2015, p. 4).

When UGC contains negative brand information, it may damage a brand, which may result in harmful consequences (Cheong and Morrison 2008). However, Colliander and Wien (2013) note that when businesses are under customer attacks, other customers may come forward on social networks to defend the brand. Customers are inclined to listen to those who do not work for the company (Colliander and Dahlén, 2011). They argue that this consumer defense phenomenon is effective in counteracting the spread of negative WOM and can even enhance the image of the brand.

\section{Methodology}

Netnography is a participant-observation method used for data collection to research the consumer behaviour of online communities and cultures present on the Internet (Kozinets, 2002). The aim of this netnographic research is to analyse the reactions of customers of grocery stores to messages posted by the grocery stores on their official Facebook pages. Facebook has been chosen, since it is the most widely used social platform companies use to engage and interact with their customers (Kabadayi and Price, 2014). The researchers have carried out 

(2013) and Colliander and Wien (2013).

For a rigorous and reliable research approach, the researchers have adhered to the five stages and procedures recommended by Kozinets (2002). The five sequential steps are (1) making entrée, (2) data collection and analysis, (3) providing trustworthy interpretation, (4) research ethics, and finally (5) member checks.

Tesco and Walmart were selected based on the 2013 Global Food Retail report, which positions them as the leading grocery stores in the world. These two grocery stores have been selected as they both have implemented an international strategy and have stores in several countries. Tesco is the grocery market leader in the UK and operates in 11 countries with 6902 shops around the world. Walmart is an American multinational retailing corporation and is the largest retailer in the world with 11,695 stores in 28 countries. Both grocery stores use social media to engage customers and Facebook is the social media platform attracting the highest number of customers for both grocery stores. In May 2017, Tesco has 2,248,822 users who have liked its page while Walmart has 33,190,043 users who have liked its page. Both Tesco and Walmart have a social media guideline to ensure that discussions are relevant and helpful for the users and that they reserve the right to delete content posted to Facebook or block users from posting if the content is deemed to be offensive, abusive, illegal or contrary to their guidelines. However, Walmart has explicitly asked its customers not to respond to customer queries directed to the company as they have a dedicated Walmart social team.

The official Facebook pages of Tesco and Walmart are relevant to the topic of the research, therefore meeting the criteria set by Kozinets (2002). On both Facebook pages, there are high numbers of postings and particularly so during the data collection period ranging from 6 April 2014 to 6 May 2014 because of the Easter Festival. Additionally, there are a large number of discrete posters on both Facebook pages.

Data were collected for a one-month period similar to the non-participant observation netnography of Colliander and Wien (2013) who examined the phenomenon of customers who defend companies and brands against negative WOM generated by other customers. Therefore a one-month period was considered a suitable length of time to capture comments and gain access to the window of the world of Tesco and Walmart social media brand communities. As recommended by Kozinets (2002), conversations occurring on the official Facebook 
pages of Tesco and Walmart were downloaded until saturation of data occurred. Similar to previous research conducted by Hsieh and Shannon (2005) and Stavros et al. (2014) on social media, the unit of analysis consisted of the content of the Facebook pages of Tesco and Walmart and the coding units were the individual posts and comments by customers of these grocery stores. For this study, the codes for the thematic analysis have been derived from the literature review as well as from the data collected itself. A directed approach to content analysis has been adopted (Hsieh and Shannon, 2005). Constant comparative method has been used to perform the qualitative data analysis with the NVivo software (Kozinets, 2002) in order to generate insights. Open coding has first been applied (Miles and Huberman, 1994) to bring meaning to the data, closely examining and comparing data for similarities and differences. Each code represents a distinct aspect of the phenomenon being studied. Then axial coding (Miles and Huberman, 1994) was used to interconnect the various categories identified in the previous stage in order to uncover any fundamental underlying trends and patterns.

The third step of netnography is to provide trustworthy interpretation (Kozinets, 2002). Kozinets (2002) argues that research is reckoned to be reasonable and trustworthy when conventional procedures of netnography are followed while collecting and analysing data. Triangulation of data has been used to enhance credibility of the study. As stipulated by Lincoln and Guba (1985), triangulation is achieved through the use of a large number of customers who have posted comments. Opinions and experiences of customers could be corroborated against viewpoints and beliefs of other customers, therefore constructing a rich picture of needs, attitudes and behaviours of the users under scrutiny (Shenton, 2004). Additionally site triangulation has been achieved through the participation of customers from two different grocery stores (Tesco and Walmart) in order to lessen the effect on the research of particular local factors belonging to one specific grocery store. Shenton (2004) debates that findings may be perceived as more credible when similar findings arise from two or more different sites.

The ethical procedure recommended by Langer and Beckman (2005) has been adopted in this research since the comments posted by customers of Tesco and Walmart on the official Facebook page are not password restricted and are available to the public. However anonymity and privacy of the participants have been respected.

Finally, the fifth step is carrying out member checks (Kozinets, 2002). Member check is a technique whereby part or all of the research findings are given to the participants of the research in order to seek their comments 
(Lincoln and Guba, 1985). However, the researchers did not carry out member checks as Langer and Beckman (2005) argued that it was unnecessary to present the findings back to members of the community who participated when the research was conducted entirely unobtrusively.

\section{Findings and Discussion}

Customers react to company initiated messages on the official Facebook pages of Tesco and Walmart by posting comments. These customer posts are a form of $\mathrm{CE}$, which embraces all consumer-to-firm interactions and consumer-to-consumer communications about the brand (Gummerus et al., 2012). This study reveals that customers engage with grocery stores by posting comments which are addressed to them and which have been grouped under the category of consumer to business conversations (C2B), and also post comments to other customers and which are referred to as consumer-to-consumer (C2C) conversations. The comments posted by customers have further been classified as favourable or unfavourable customer posts for the grocery stores. The main findings of the study have been summarised in Table 1, and examples of customer posts have been provided. The verbatim quotes used are representative of the online world of blog post communication. It is the nature of postings that they are short and not rich, detailed or necessarily explicit in their meaning. Insert Table 1 here

\subsection{C2B conversations}

Customers engage in conversations with grocery stores to participate by taking actions desired by Tesco and Walmart for e.g. answering questions. C2B conversations also arise when customers post queries directly related to the company post. When Tesco and Walmart post an advertisement for a product or service, customers want to know more about the price, availability, conditions attached to the offer, the features and benefits of the product, advice and explanation of how to use the product or service. This corroborates findings of Brodie et al. (2011b) who found that in virtual communities, conversations occur on prices, performance, quality and personal experiences with specific brands. Similarly, Park and Kim (2014) identified informational benefits as one of the motivators of customers for joining brand social networks. Customers also use the official Facebook page of Tesco and Walmart to obtain further information irrespective of the content of the company post. They just comment on any company posts, by posting their unrelated queries. This clearly indicates that customers perceive the official Facebook page of Tesco and Walmart as a direct communication channel. Such 
unrelated queries confirm that businesses can no longer simply publish content they wish potential customers to see (O’Brien, 2011).

Customers also seek entertainment benefits from virtual communities. Customers seem to interact more with companies on their Facebook page when company posts involve fun and enjoyment. For instance Walmart had a game on Easter day inviting customers to tell the number of eggs they could find in a picture. This Walmart post obtained an overwhelming 21829 comments posted by customers indicating the number of eggs they could locate. This corroborates the findings of Park and Kim (2014) who postulate that entertainment benefits motivate community participation.

When communicating to Tesco and Walmart, customers at times inform companies about the type of benefit they would like to get. Muntinga et al. (2009) refer to this behaviour as remuneration. Similarly, Hennig-Thurau et al. (2004) found that brand-related online activities may be partly driven by prospects of money, job-related benefits or other rewards. So while communicating back to the grocery stores, customers of Tesco and Walmart look for informational, functional, entertainment and economic benefits.

Among the $\mathrm{C} 2 \mathrm{~B}$ conversations, some customers post comments, which either add or destroy value for the grocery stores. These comments have been categorised as favourable and unfavourable customer posts. Favourable customer posts turn customers into co-creators of value, while unfavourable customer posts make customers become co-destructors of value.

When satisfied customers post positive comments and show their appreciation to grocery stores, they generate positive WOM, which adds value for the company. Sashi (2012) refers to these customers as advocates. Similarly Dessart et al. (2015) acknowledge customer referral as a form of behavioural CE and term it as endorsing. Moreover, while replying to company initiated messages, customers at times make suggestions to the company and these suggestions turn customers into co-creators of value for the organisation (O'Cass and Viet Ngo, 2011). Additionally, this study reveals that customers willingly inform the company of the products or services that they would want the store to offer for sale. These types of comments are very valuable for any organisation as the customer is readily providing marketing intelligence, thus creating value for the business. Verhoef et al. (2010) argue that co-creation is a form of CE, which contributes to perceived consumer empowerment (Füller et al., 2009). Loyal customers post favourable comments, which may positively impact the organisation. For example customers post comments to tell the company what makes them patronise the store. Dessart et al. (2015) argue that prolonged CE with a brand can result in customer loyalty. 
'Thanks for Tesco, And all the local \& express Store's [sic], i [sic] for one appreciate polite staff and bargain prices every day thanks Tesco, I'me [sic] a BIG FAN!! [sic]'

However, this study also reveals that instead of generating CE, Tesco and Walmart causes customer enragement when customers destroy value by posting negative comments. These negative comments are negative WOM and are detrimental to the organisation (Colliander and Wien, 2013). Customers use the Facebook page of the grocery stores to complain about a product or service. Similarly, Jin (2012) claims that many customers write to companies on the companies' Facebook pages to complain when they are dissatisfied with a product. Customers at times complain about something directly related to a company post, but they also post complaints not linked to the company post. This shows that customers see this Facebook page as a direct communication channel with grocery stores.

Additionally, analysis of data reveals that customers post messages to criticise actions taken by Tesco and Walmart. Customers express their discontent about the actions taken by the company and not its products. For e.g. customers are very critical of Tesco as a profit making business. Some customers feel that Tesco is driven solely by its profit motive and does not pay enough attention to the welfare of customers or to the society in general as illustrated by the comment below:

'Tesco will celebrate when they know they can make money from it.'

Brodie et al. (2011b) warn that interventions of marketers are accepted in online communities only if they contribute to the community and that customers tend to react negatively when marketers have commercially driven communications. In such cases, the customers expressed their feelings of discontent by posting sarcastic and sceptic comments. Comments are labeled as sarcastic when irony is used to mock or to convey contempt. Customers post such comments to express their anger and/or disappointment following an action of the company or an event that has occurred. Sarcasm brings negative value and can potentially harm the relationship between the two parties. This study reveals that sarcasm is the most common form of emotional expression on Tesco and Walmart Facebook pages. Tesco posted a question to ask customers about any exotic food they would like to taste. Numerous customers commented sarcastically referring to the horsemeat scandal in which Tesco was allegedly involved: 'Maybe [sic] a random foodie question from me.... Are you still selling horse?'

The sarcastic comments indicate clearly that these customers have not forgotten the horsemeat scandal, and that 
they are still upset. Sarcastic comments may indicate that the relationships between Tesco and its customers have been damaged.

Customers also express scepticism when posting comments. Sceptic comments are those comments that incorporate an element of doubt or lack of conviction about something. Customers let companies know that they remain dubious or have a feeling of incredulity about promises made by companies. Sceptic comments are posted when customers have lost trust in the company and this may damage or have already damaged the relationship between the customer and the company. For instance, for an offer that seemed very interesting, a customer posted a comment asking about hidden conditions attached to that offer:

'Sure. Whats [sic] the catch?'

However, analysis of the $\mathrm{C} 2 \mathrm{~B}$ conversations reveals that customers post comments to express positive emotions. Customers post or share comments when they are emotionally or cognitively involved to some degree with the company post (Yu, 2014). From an emotional perspective, CE may be characterised by feelings of an individual towards a brand (Vivek et al., 2012). Customers have expressed their emotions by posting enthusiastic and humourous comments.

Enthusiasm echoes an individual's core level of interest and excitement about the virtual community while enjoyment mirrors the level of pleasure and happiness felt by the customer when interacting with the online brand community and its members (Dessart et al., 2015). Enthusiasm is associated with positive emotions felt by customers who post enthusiastic comments when they are happy or excited and they express their hedonic shopping value. Customers use humour in their comments when they find an event or a situation amusing or funny. This form of CE brings positive value to the OBC (Kumar et al., 2010).

From the examples provided above, it is clear that customers of Tesco and Walmart have been empowered since they can express their opinion by posting comments in which they share their emotions with others. When members of the community are emotionally engaged, the nature of the relationship changes (Brodie et al., 2011a; Harridge-March and Quinton, 2009). Positive emotions linked with enthusiasm and humour, tend to strengthen the relationship between the grocery store and the customer, while negative emotions related with sarcasm and scepticism may damage the relationship between the two parties. 


\subsection{Consumer-to-Consumer (C2C) conversations}

The other type of conversation occurring on the Facebook pages of Tesco and Walmart is C2C conversations where customers engage in dialogues with other customers. During these C2C conversations, customers post comments in which they offer advice to other members of the community or help other customers within the community. This represents behavioural CE (van Doorn et al., 2010) incorporating customer co-creation. The study further reveals that customers post comments in response to another customer's query. They provide the answer or solution to their peer in lieu of the company. They act as co-helpers by assisting fellow customers and hence creating social benefits (Gummerus et al., 2012). Customers who help other customers are valuable to organisations as they provide customer service on behalf of these companies.

Customers also criticise other customers when they disagree with comments posted by complainants. They openly criticise other customers whom they believe are wrong. When customers defend a company when faced with negative UGC, it is a highly appealing form of behavioural customer engagement for the organisation as it shows high level of customer loyalty (Dessart et al., 2015). Colliander and Wien (2013) argue that very often customers respond to complaints before the companies do by giving the company the benefit of the doubt. For e.g. several customers accused Tesco of being driven only by profit motives when it advertised for its new Tesco Current Account and a customer defended the store by posting the following:

'Omg [sic] Tesco is a competitive business just like everything else OBV [sic] there Guna [sic] make profit etc! Get it! ... If u [sic] don't like them don't comment',

Additionally Kumar et al. (2010) contend that customer loyalty is triggered through positive online interactions with the brand and the community members and by actively defending the company when faced with negative UGC. These favourable comments that are posted during the $\mathrm{C} 2 \mathrm{C}$ conversations add value for the grocery stores.

However destruction of value also occurs during $\mathrm{C} 2 \mathrm{C}$ conversations. Customers use the Facebook pages of Tesco and Walmart to provide information about better deals at competitors' outlets, hence destroying value. The ability to provide information about competitors has given a voice to the customer (Daugherty et al., 2008). Likewise, Bernoff and Schadler (2010) cautioned that in this era anyone with a smartphone or a computer could instantly inflict lasting brand damage.

Customers also post comments to warn customers about some products, and this negative WOM will most 
probably damage the image of the brand (Cheong and Morrisson, 2008). Other customers also claim to have moved to competitors' stores and have posted comments to inform the OBC. Findings also reveal that customers show empathy to customers whom they believe have been treated unjustly by the grocery stores. When customers provide support to other customers on Facebook, it puts additional pressure on the company to solve the issues raised by customers. This shows how social media have empowered customers who now can easily publicise the problems they are facing and gain support from the other members of the community (Lee et al., 2014). These unfavourable comments may influence customers to shop elsewhere, as customers in this social media era tend to rely more on customer reviews than advertising (Lim et al., 2012).

Co-destruction of value arises during interactions between the company and its customers where instead of creating value for both parties, value is destroyed (Plé and Chumpitaz Cáceres, 2010; Smith, 2013) Though a qualitative approach has been adopted, it was observed that an overwhelming $65.79 \%$ of comments posted by customers on the Facebook pages of Tesco and Walmart are categorised as negative comments for the grocery store. This clearly illustrates that customers take to Facebook to vent their frustration when grocery stores do not live up to their expectations.

\section{Conclusion}

The aim of this paper was to explore the role played by OBCs and social customers in the creation as well as the destruction of value. This has been addressed through an analysis of the reactions of customers to company initiated messages on Facebook pages of Tesco and Walmart. Findings have revealed that customers engage in conversations with Tesco and Walmart seeking informational, functional, entertainment and economic benefits. Additionally, this paper has shown that customers are cognitively, emotionally and behaviourally engaged while interacting on the Facebook pages of Tesco and Walmart. And finally, findings show that social customers can be both a blessing and a curse to Tesco and Walmart as they can create or destroy value for the business.

In addressing issues that surround the role of social media in the co-creation and co-destruction of customer, consumer and supermarket value this paper builds theory and informs practice. Operating at the theory-practice interface it contributes to and extends academic debates in the areas of social media, brand communities, branding, marketing, value creation, and value destruction. Customers become co-creators of value when they offer advice or help other customers within the community, when they refer products or services to other customers, when they make suggestions to the grocery stores, and when they defend the company and its employees. Additionally, Facebook empowers customers to co-create value when they act as customer care 
officers while replying to queries of other customers or providing solutions to solve problems faced by other customers. Another contribution of this paper is to add knowledge to the body of literature on co-destruction of value by identifying the various ways customers can harm and threaten grocery stores on Facebook. Codestruction of value occurs whenever customers complain, criticise actions of the companies, recommend their peers to boycott the grocery stores and to patronise outlets of competitors. These actions of customers harm the organisation as they destroy value (Leeflang et al., 2014, Verhoef et al., 2013). Additionally, this study contributes to knowledge by positioning Facebook as a customer service channel, where customers expect companies to respond to their queries, or to solve the problems they are facing in real-time.

The results of this study suggest a number of implications for retailing, marketing and brand managers. Grocery stores are increasingly using social media to drive meaningful conversations with customers and to connect with them. Managers should know how to harness social media to enrich the customer experience through customer engagement. This can be achieved by using the information that customers unknowingly or willingly reveal about themselves to personalise the customer experience by sending accurately targeted information. Additionally, since customers have turned the Facebook page into a customer service channel, businesses should provide multi level customer service channel so that customers can choose through which channel they wish their queries or complaints be dealt with. This may help businesses to provide service to individual customers more efficiently, thus leading to higher customer satisfaction level. Businesses should also encourage customers to co-create value. This can be achieved by making customers aware that their voices have been heard and inform them about actions that the firm has taken so that customers feel valued which will further motivate them to co-create value.

The limitation of the paper is related to the nature of the netnography method, which constrained the analysis to those customers who have commented on Facebook, therefore neglecting other sources such as offline customer feedback. Another limitation is that the authors have used only one social media platform, Facebook, which is the platform where both Tesco and Walmart have the highest number of customers. Future research might offer a comparative analysis of the use of Facebook by grocery stores and might also analyse the social media strategies adopted by these firms. Another avenue for future research could be to focus on one grocery store operating in several countries to identify differences and similarities between social media communication in different country contexts. As this research spanned over a one-month period, future researchers could conduct a similar study for the same or different month in another year to act as a point of comparison. This is in essence a 
baseline netnographic study that is time and space bound and that can therefore be reproduced for the purposes

of comparative study.

\section{References}

Abdul-Ghani, E., Hyde, K.F. and Marshall, R. (2011) "Emic and Etic Interpretations of Engagement with a Consumer-to-Consumer Online Auction Site". Journal of Business Research. 64 (10), pp1060-1066.

Anderson, K., Knight, D., Pookulangara, S., Josiam, B. (2014) "Influence of hedonic and utilitarian motivations on retailer loyalty and purchase intention: a Facebook perspective". Journal of Retailing and Consumer Services. 21, pp773-779.

Arnaboldi, M. and Coget, J. (2016) "Social media and business". Organizational Dynamics. pp47-54, http://dx.doi.org/10.1016/j.orgdyn.2015.12.006.

Ballings, M. and Van den Poel, D. (2015) "CRM in social media: Predicting increases in Facebook usage frequency". European Journal of Operational Research. 244 (1), pp248-260, http://dx.doi.org/10.1016/j.ejor.2015.01.001.

Bernoff, J. and Schadler, T. (2010) "Empowered”. (cover story). Harvard Business Review. 88 (7/8), pp94-101.

Bijmolt, T., Leeflang, P., Block, F., Eisenbeiss, M., Hardie, B., Lemmens, A. and Saffert, P. (2010) "Analytics for Customer Engagement". Journal of Service Research. 13 (3), pp341-356.

Blasco-Arcas, L., Hernandez-Ortega, B.I. and Jimenez-Martinez, J. (2016) "Engagement platforms: the role of Emotions to foster customer engagement and brand image in interactive media". Journal of Service Theory and Practice. 26 (5) pp559-589.

Brodie, R.J., Hollebeek, L.D., Juric, B. and Ilic, A. (2011a) "Customer Engagement: Conceptual Domain, Fundamental Propositions, and Implications for Research". Journal of Service Research. 14 (3), pp252271.

Brodie, R.J., Ilic, A., Juric, B. and Hollebeek, L. (2011b) "Consumer engagement in a virtual brand community: An exploratory analysis". Journal Of Business Research, 66 (1), pp105-114.

Champoux, V., Durgee, J., and McGlynn, L. (2012) "Corporate Facebook pages: when "fans" attack". Journal of Business Strategy. 33 (2), pp22 - 30.

Cheong, H. and Morrison, M. (2008) 'Consumers' Reliance on Product Information and Recommendations Found in UGC". Journal Of Interactive Advertising. 8 (2), pp38-49.

Colliander, J. and Dahlén, M. (2011) "Following the Fashionable Friend: The Power of Social Media". Journal Of Advertising Research. 51 (1), pp313-320.

Colliander, J. and Wien, A.H. (2013) "Trash talk rebuffed: consumers' defense of companies criticized in online communities". European Journal of Marketing. 47 (10), pp1733-1757.

Constantinides, E., Romero, C. and Boria, M. (2008) "Social Media: A New Frontier for Retailers?". European Retail Research. 22, pp1-28.

Daugherty, T., Eastin, M.S. and Bright, L. (2008) "Exploring consumer motivations for creating user generated content". Journal of Interactive Advertising. 8 (2), pp6-25.

De Vries, L., Gensler, S. and Leeflang, P. (2012) "Popularity of brand posts on brand fan pages: An investigation of the effects of social media marketing". Journal of Interactive Marketing. 26, pp83-91.

Demangeot, C. and Broderick, A.J. (2016) "Engaging customers during a website visit: a model of website customer engagement". International Journal of Retail \& Distribution Management. 44 (8), pp814 -839.

Dessart, L., Veloutsou, C. and Morgan-Thomas, A. (2015) "Consumer engagement in online brand communities: A social media perspective”. Journal of Product \& Brand Management. 24 (1), pp1 - 33. 
Echeverri, P. and Skålén, P. (2011) "Co-creation and co-destruction: A practice-theory based study of interactive value formation". Marketing Theory. 11(3), pp351-373. http://dx.doi.org/10.1177/1470593111408181.

Einwiller, S.A. and Steilen, S. (2015) "Handling complaints on social network sites - An analysis of complaints and complaint responses on Facebook and Twitter pages of large US companies". Public Relations Review, 41(2), pp195-204, http://dx.doi.org/10.1016/j.pubrev.2014.11.012.

Fournier, S. and Avery, J. (2011) “The uninvited brand”. Business Horizons. 54, pp193-207.

Füller, J., Mühlbacher, H., Matzler, K. and Jawecki, G. (2009) "Consumer Empowerment Through InternetBased Co-creation”. Journal Of Management Information Systems. 26 (3), pp71-102.

Gonzalez-Lafaysse, L. and Madrid, C. (2016) "Facebook and sustainable development: a case study of a French supermarket chain". International Journal of Retail \& Distribution Management. 44 (5) pp560 - 582.

Greenberg, P. (2010) "The impact of CRM 2.0 on customer insight". Journal of Business \& Industrial Marketing,. 25 (6), pp410-419.

Gummerus, J., Liljander, V., Weman, E. and Pihlström, M. (2012) "Customer engagement in a Facebook brand community”. Management Research Review. 35 (9), pp857 - 877.

Harridge-March, S. and Quinton S. (2009) "Virtual snakes and ladders: social networks and the relationship marketing loyalty ladder". Marketing Review. 9 (2), pp71-181.

Harrison, T. and Barthel, B. (2009) "Wielding new media in Web 2.0: exploring the history of engagement with the collaborative construction of media products". New Media Society. 11 (1-2), pp155-178.

Hennig-Thurau, T., Gwinner, K.P., Walsh, G. and Gremler, D.D. (2004) "Electronic word-of-mouth via consumer opinion platforms: what motivates consumers to articulate themselves on the Internet?". Journal of Interactive Marketing. 18 (1), pp38-52.

Hennig-Thurau, T., Hofacker, C.F., and Bloching B. (2013) "Marketing the Pinball Way: Understanding How Social Media Change the Generation of Value for Consumers and Companies". Journal of Interactive Marketing. 27 (4), pp237-241.

Ho, C. (2014) “Consumer behavior on Facebook”, EuroMed Journal of Business. 9 (3), pp252 - 267.

Hoffman, D.L. and Fodor, M. (2010) “Can you measure the ROI of your social media marketing?". MIT Sloan Management Review. 52 (1), pp. 41-49.

Hollebeek, L. (2011) "Demystifying customer brand engagement: Exploring the loyalty nexus". Journal of Marketing Management .27 (7/8), pp785-807.

Horn, I., Taros, T., Dirkes, S., Huer, L., Rose, M., Tietmeyer, R. and Constantinides, E. (2015) "Business Reputation and Social Media - A Primer on Threats and Responses". IDM Journal of Direct, Data and Digital Marketing Practice. 16 (3), pp 193-208.

Hsieh, H. and Shannon, S. (2005) "Three approaches to qualitative content analysis". Qualitative Health Research. 15 (9), pp1277-1288.

Jansen, B.J., Zhang, M., Sobel, K. and Chowdury, A. (2009) "Twitter power: tweets as electronic word of mouth". Journal of the American Society for Information Science and Technology. 60 (11), pp21692188.

Jin, S.A. (2012) "The potential of social media for luxury brand management". Marketing Intelligence \& Planning. 30 (7), pp687 - 699.

Jurgens, M., Berthon, P., Edelman, L. and Pitt, L. (2016) "Social media revolutions: The influence of secondary stakeholders". Business Horizons. 59 (2), pp.129-136, http://dx.doi.org/10.1016/j.bushor.2015.11.010.

Kietzmann, J.H., Hermkens, K., Mccarthy, I.P. and Silvestre, B.S. (2011) "Social Media? Get Serious! Understanding the functional building blocks of social media". Business Horizons, 54, pp241-251. 
Kimmel, A. (2010) Connecting with consumers: marketing for new marketplace realities. Oxford: University Press.

Kozinets, R.V. (2002) "The field behind the screen: using netnography for marketing research in online communities". Journal of Marketing Research. 39, pp61-72.

Krishnamurthy, S., Kucuk, S.U. (2009) “Anti-branding on the Internet”. Journal of Business Research. 62 (11), pp1119-26.

Kumar, V., Aksoy, L., Donkers, B., Venkatesan, R., Wiesel, T. and Tillmanns, S. (2010) "Undervalued or Overvalued Customers: Capturing Total Customer Engagement Value”. Journal of Service Research. 13 (3), pp297-310.

Labrecque, L.I. (2014) "Fostering Consumer-Brand Relationships in Social Media Environments: The Role of Parasocial Interaction”. Journal of Interactive Marketing. 28 (2), pp134-148, http://dx.doi.org/10.1016/j.intmar.2013.12.003.

Langer, R. and Beckman, S.C. (2005) "Sensitive research topics: netnography revisited". Qualitative Market Research: an International Journal. 8 (2), pp189-203.

Lee, H., Han, J. and Suh, Y. (2014) "Gift or threat? An examination of voice of the customer: The case of MyStarbucksIdea.com”. Electronic Commerce Research and Applications. 3 (13), pp205-219, http://dx.doi.org/10.1016/j.elerap.2014.02.001.

Leeflang, P.S.H., Verhoef, P.C., Dahlström, P. and Freundt, T. (2014) "Challenges and solutions for marketing in a digital era". European Management Journal. 32, pp1-12.

Lincoln, Y.S. and Guba, E.G. (1985) Naturalistic Inquiry. Beverly Hills, CA: Sage Publications.

Lipsman, A., Mudd, G., Rich, M. and Bruich, S. (2012) "The Power of "Like" How Brands Reach and Influence Fans Through Social-Media Marketing”. Journal Of Advertising Research. 52 (1), pp40-52.

Lovejoy, K., Waters, R.D. and Saxton, G.D. (2012) "Engaging stakeholders through Twitter: How nonprofit organizations are getting more out of 140 characters or less". Public Relations Review. 38, pp313- 318.

Lusch, R.F. and Vargo, S.L. (2006) "Service-dominant logic: reactions, reflections and refinements". Marketing Theory. 6 (1), pp281-288.

Malthouse, E., and Hofacker, C. (2010) "Looking back and looking forward with interactive marketing", Journal of Interactive Marketing, 24(3), pp181-184.

Manchanda, P., Packard, G. and Pattabhitamaiah, A. (2012) "Social dollars: The economic impact of consumer participation in a firm-sponsored online community”. Marketing Science Institute. 34 (3), pp367-387.

Mangold, W.G. and Faulds, D.J. (2009) "Social media: The new hybrid element of the promotion mix". Business Horizons. 52, pp357-365.

Muntinga, D., Moorman, M. and Smit, E. (2011) "Introducing COBRAs". International Journal Of Advertising. $30(1), \mathrm{pp} 13-46$.

Newman, N., Levy, D. A. L. and Nielsen, R. K. (2016) Reuters Institute Digital News Report

O'Brien, C. (2011) “The emergence of the social media empowered consumer". Irish Marketing Review. 21 $(1 / 2)$, pp32-40.

O'Cass, A. and Viet Ngo, L. (2011) "Achieving customer satisfaction in services firms via branding capability and customer empowerment”. Journal of Services Marketing. 25 (7) pp489 - 496.

Park, H. and Kim, Y.K. (2014) "The role of social network websites in the consumer-brand relationship". Journal of Retailing and Consumer Services. 21, pp460-467. 
Patterson, P., Yu, T. and De Ruyter, K. (2006) "Understanding customer engagement in services". paper presented December 4-6 at ANZMAC 2006 Conference: Advancing Theory, Maintaining Relevance, Brisbane.

Pereira, H.G., Salgueiro, M.F. and Mateus, I. (2014) "Say yes to Facebook and get your customers involved! Relationships in a world of social networks". Business Horizons. 57 (6), pp695-702, http://dx.doi.org/10.1016/j.bushor.2014.07.001.

Pfeffer, J., Zorbach, T. and Carley, K.M. (2014) "Understanding online firestorms: Negative word-of-mouth dynamics in social media networks". Journal of Marketing Communications. 20 (1-2), pp117-128, DOI: 10.1080/13527266.2013.797778.

Plé, L. and Chumpitaz, C.R. (2010) "Not always co-creation: introducing interactional co-destruction of value in servicedominant logic”. Journal of Services Marketing. 24 (6), pp430 - 437.

Pongpaew, W., Speece, M. and Tiangsoongern, L. (2014) "Social Presence and Customer Brand Engagement in Corporate Facebook". paper presented at the 12th EBES Conference, Singapore.

Pöyry, E., Parvinen, P. and Malmivaara, T. (2013) "Can we get from liking to buying? Behavioral differences in hedonic and utilitarian Facebook usage". Electronic Commerce Research and Applications. 12, pp224235.

Rageh, A., Melewar, T. and Woodside, A. (2013) "Using netnography research method to reveal the underlying dimensions of the customer/tourist experience". Qualitative Market Research: An International Journal.16 (2), pp126-149.

Rao, S. (2012) "Facebook for businesses". Vikalpa: The Journal For Decision Makers. 37 (4), pp90-92.

Sashi, C.M. (2012) “Customer engagement, buyer-seller relationships, and social media". Management Decision. 50 (2), pp253 - 272.

Schultz, D.E. and Peltier, J. (2013) "Social media's slippery slope: challenges, opportunities and future research directions". Journal of Research in Interactive Marketing. 7 (2), pp86-99.

Shao, G. (2009) "Understanding the appeal of user-generated media: a uses and gratification perspective". Internet Research. 19 (1), pp7 - 25.

Shenton, A.K. (2004) "Strategies for ensuring trustworthiness in qualitative research projects". Education for Information. 22, pp63-75.

Smith, A.M. (2013) "The value co-destruction process: a customer resource perspective". European Journal of Marketing. 47 (11/12), pp1889- 1909.

Stavros, C., Meng, M.D., Westberg, K. and Farrelly, F. (2014). "Understanding fan motivation for interacting on social media". Sport Management Review. 17, pp455-469.

Swani, K., Milne, G. and Brown, B.P. (2013) "Spreading the word through likes on Facebook". Journal of Research in Interactive Marketing. 7 (4), pp269 - 294.

Thackeray, R., Neiger, B.I., Hanson, C.L. and McKenzie, J.F. (2008) "Enhancing promotional strategies within social marketing programs: use of Web 2.0 social media". Health Promotion Practice. 9 (4), pp338-343.

Tiruwa, A., Yadav, R. and Suri P.K. (2016) "An exploration of online brand community (OBC) engagement and customer's intention to purchase". Journal of Indian Business Research. 8 (4), pp295 - 314.

Tsimonis, G. and Dimitriadis, S. (2014) "Brand strategies in social media". Marketing Intelligence \& Planning. $32(3)$, pp328-344.

Ureña, G.V., Herrera Murillo, D., Herrera Murillo, N. and Martínez Garza, F.J. (2015.) "Purposes of the communication between companies and their Facebook followers". Revista Latina de Comunicación Social. 70, pp110-121. DOI: 10.4185/RLCS-2015-1037en. 
van Doorn, J., Lemon, K.N., Mittal, V., Nass, S., Pick, D., Pirner, P. and Verhoef, P.C. (2010) "Customer Engagement Behavior: Theoretical Foundations and Research Directions". Journal of Service Research. 13 (3), pp253-266.

Vargo, S. L., and Lusch, R. F. (2010) "From repeat patronage to value cocreation in ecosystems: a transcending conceptualization of relationship". Journal of Business Market Management. 4(4), pp169-79.

Verhoef, P.C., Beckers, S. and van Doorn J. (2013) “Understand the Perils of Co-Creation”. Harvard Business Review. 91 (9), pp28-32.

Verhoef, P.C., Reinartz, W.J. and Krafft, M. (2010) "Customer Engagement as a New Perspective in Customer Management”. Journal of Service Research. 13 (3), pp247-252.

Vivek, S., Beatty, S. and Morgan, R. (2012) "Customer Engagement: Exploring Customer Relationships Beyond Purchase". Journal Of Marketing Theory \& Practice. 20 (2), pp122-146.

Wirtz, J., den Ambtman, A., Bloemer, J., Horváth, C., Ramaseshan, B., van de Klundert, J., Zeynep Gurhan, C. and Kandampully, J. (2013) "Managing brands and customer engagement in online brand communities", Journal of Service Management. 24 (3), pp223-244.

Yadav, M.S. and Pavlou, P.A. (2014) "Marketing in computer-mediated environments: research synthesis and new directions", Journal of Marketing. 78(1), pp20-40.

Yadav, R. (2015), "An Exploration into the Nature of Comments on Facebook (Page of Large Indian Organizations)". In Managing in Recovering Markets. pp. 103-112, Springer India.

Yu, J. (2014) "We Look for Social, Not Promotion: Brand Post Strategy, Consumer Emotions, and Engagement A Case Study of the Facebook Brand Pages". GSTF International Journal on Media \& Communications (JMC). 1 (2), pp28-36. 
Table 1: Findings of the study

\begin{tabular}{|c|c|c|c|c|}
\hline \multirow{8}{*}{ C2B } & \multicolumn{2}{|c|}{ Favourable customer posts } & \multicolumn{2}{|c|}{ Unfavourable customer posts } \\
\hline & Type & Example & Type & Example \\
\hline & Customer query & $\begin{array}{l}\text { 'Are these for toddlers and up? Are } \\
\text { they in infant sizes?' }\end{array}$ & Complain & $\begin{array}{l}\text { "Not a lot, after just going to Tesco I } \\
\text { came home empty handed! Most things } \\
\text { are out of stock, buy } 1 \text { get } 1 \text { free but only } \\
1 \text { of the items left! Bread with tomorrow's } \\
\text { date on it, pathetic for Tesco! One angry } \\
\text { customer I am afraid" }\end{array}$ \\
\hline & $\begin{array}{l}\text { Participation - perform } \\
\text { action desired by company }\end{array}$ & $\begin{array}{l}\text { "Chicken and lamb potatoes mixed } \\
\text { veg and mushrooms gravy followed } \\
\text { by Easter cake Easter eggs" }\end{array}$ & $\begin{array}{l}\text { Criticise action of the } \\
\text { company }\end{array}$ & $\begin{array}{l}\text { "Why should I shop at Walmart when I } \\
\text { could spend my money at a more modern } \\
\text { and fun store? Walmart is one of the last } \\
\text { stores to use pork suppliers that still use } \\
\text { pig gestation crates. It is a cruel practice, } \\
\text { one that Walmart could easily stop if they } \\
\text { wanted to." }\end{array}$ \\
\hline & Express enthusiasm & "YES I've been waiting for this!" & Post sarcastic comments & $\begin{array}{l}\text { "Could of [sic] eaten anything from Tesco } \\
\text { don't think you have a clue what's in your } \\
\text { meat given the recent horse meat scandal } \\
\text { !! [sic]" }\end{array}$ \\
\hline & Express humour & $\begin{array}{l}\text { "Yum yum.... cake on good Friday } \\
\text {...Tart on Sunday ... scales on } \\
\text { Monday lol [sic]" }\end{array}$ & Post sceptic comments & $\begin{array}{l}\text { "Won a bunny but sadly no voucher } \\
\text { arrived via email - thanks for nothing - I } \\
\text { would be interested to know if any one }\end{array}$ \\
\hline & $\begin{array}{l}\text { Ask for additional } \\
\text { incentive }\end{array}$ & $\begin{array}{l}\text { 'Aren't you even giving it as a prize? } \\
\text { Yummy.' }\end{array}$ & & actually won a hudl?” \\
\hline & $\begin{array}{l}\text { Provide suggestions to the } \\
\text { company }\end{array}$ & $\begin{array}{l}\text { "If you could get more employees to } \\
\text { man your north little rock store, that } \\
\text { would be great. A back up of } 100 \\
\text { customers and only } 5 \text { registers open } \\
\text { is not good" }\end{array}$ & & \\
\hline
\end{tabular}




\begin{tabular}{|c|c|c|c|c|}
\hline \multirow[t]{3}{*}{$\mathrm{C} 2 \mathrm{C}$} & Customer Referral & $\begin{array}{l}\text { "I've only just begun shopping } \\
\text { with Tesco but I must say, so far, } \\
\text { I'm impressed. The quality is } \\
\text { much better than my previous } \\
\text { store choice \& the driver was } \\
\text { helpful \& kind, despite his } \\
\text { obviously heavy work load [sic] } \\
\text { \& the abysmal weather, he was } \\
\text { happy to carry my shopping } \\
\text { through to my kitchen \& waited } \\
\text { for me to check the dates without } \\
\text { rushing me. Yes there were a few } \\
\text { things that were closer to the } \\
\text { bblub [sic] dates than I'd have } \\
\text { liked, but the short u/b's [sic] I } \\
\text { froze \& the short b/b's [sic] I just } \\
\text { kept a close eye on \& use them } \\
\text { before they went to waste. I } \\
\text { would highly recommend Tesco's } \\
\text { [sic] \& am having another } \\
\text { delivery tomorrow. I switched to } \\
\text { Tesco's [sic] because of the new } \\
\text { £1 delivery \& the clubcard } \\
\text { points, and I'm so glad I did" }\end{array}$ & $\begin{array}{l}\text { Provide information } \\
\text { about competitors }\end{array}$ & $\begin{array}{l}\text { "Going to asda [sic] to get the eggs } \\
\text { cheaper or Aldi" }\end{array}$ \\
\hline & $\begin{array}{l}\text { Give advice to other } \\
\text { customers }\end{array}$ & $\begin{array}{l}\text { "If you buy something on Tesco at } \\
\text { reduced cost and it scans at higher } \\
\text { cost then complain You will get the } \\
\text { item free plus double your mpney } \\
\text { [sic] back, it has happened to me on } \\
\text { several occasions This is Tesco } \\
\text { policy but perhaps not many people } \\
\text { know about it. }\end{array}$ & $\begin{array}{l}\text { Warn customers against } \\
\text { a product or service }\end{array}$ & $\begin{array}{l}\text { "do [sic] not buy Banquet products. } \\
\text { they [sic] cage their chickens." }\end{array}$ \\
\hline & Help other customer & $\begin{array}{l}\text { 'click on the link provided (it worked } \\
\text { for me) and search on that site' }\end{array}$ & $\begin{array}{l}\text { Retaliate - inform } \\
\text { customers of actions } \\
\text { taken out of }\end{array}$ & $\begin{array}{l}\text { "Sorry Tesco, but I have defected to } \\
\text { Aldi! They let me buy one item at a } \\
\text { good price without making me buy }\end{array}$ \\
\hline
\end{tabular}




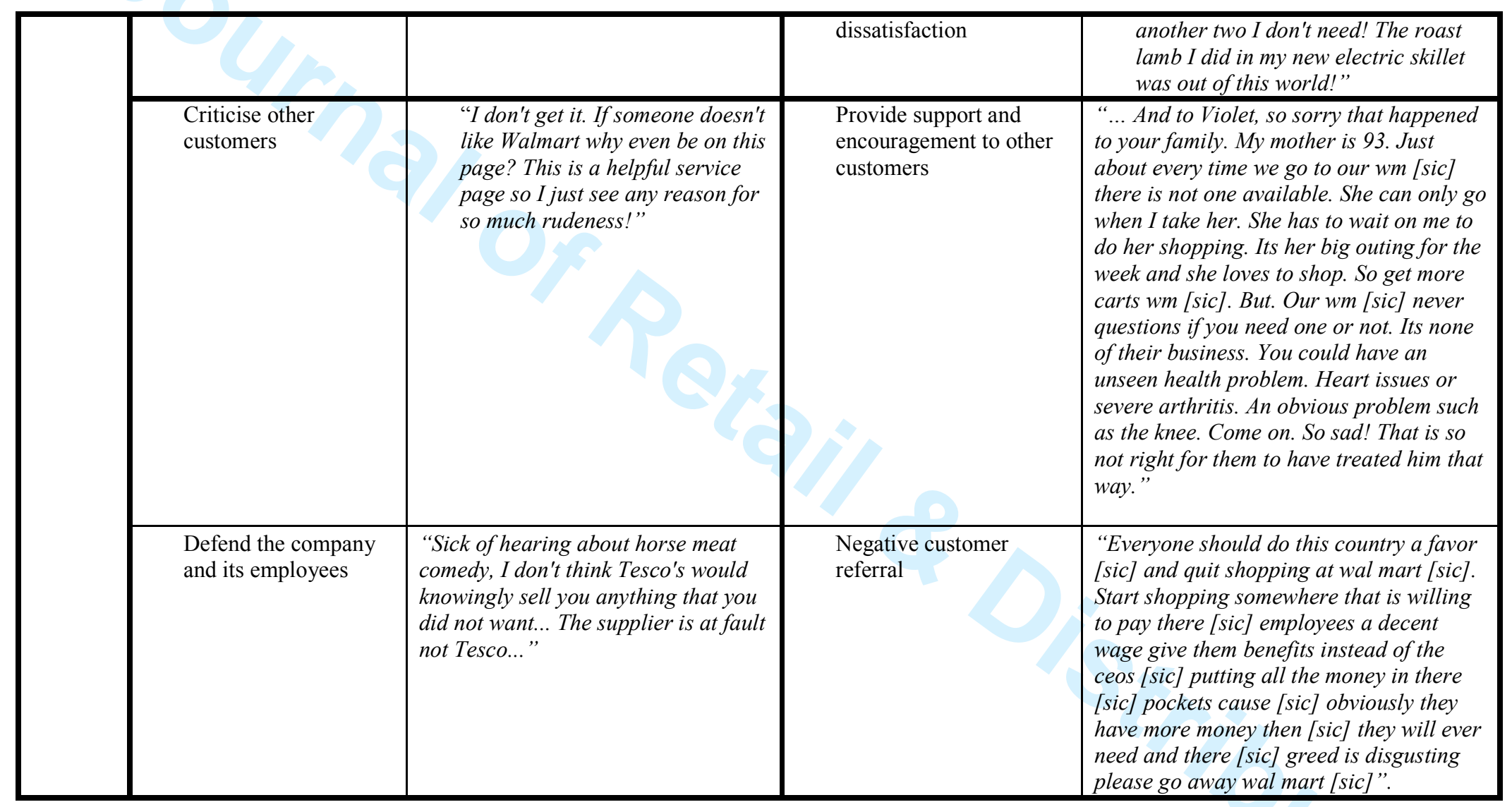

